\title{
An initial aproximation to the meteo-marine conditions of South Bay (Doumer island) and comparison of the meteorological behaviour between Doumer and Anvers islands, Antarctica (austral summer 2016-2017)
}

Aproximación inicial a las condiciones meteo-marinas en bahía Sur (isla Doumer) y comparación del comportamiento meteorológico de las islas Doumer y Anvers, Antártica (verano austral 2016-2017)

Nancy Villegas ${ }^{1}$, Igor Málikov² \& César Cárdenas ${ }^{3}$

\begin{abstract}
In order to contribute to the meteo-marine knowledge of the Western Antarctic Peninsula (WAP), the behavior of some atmospheric characteristics of South Bay is described and meteorological differences were identified in two islands of the Palmer Archipelago (south of the Gerlache Strait). The data was obtained during the III Colombian Antarctic Expedition in the Austral summer 2016-2017. The series of air temperature, relative humidity, dew point temperature, wind direction and wind speed at Doumer Island were compared with those recorded at Anvers Island and with sea temperature behavior at $10 \mathrm{~m}$ depth in South Bay (Doumer Island). It was concluded that although Anvers and Doumer Islands are neighboring, the behavior of meteo-marine variables in the Austral summer 2016-2017 differs.
\end{abstract}

\section{Key words:}

Western Antarctic Peninsula, Palmer Archipelago, meteorology, seawater temperature.

\section{Resumen}

Con el fin de aportar al conocimiento meteomarino del sector Oeste de la Península Antártica, se describió el comportamiento de algunas características atmosféricas de la bahía Sur y se identificaron las diferencias meteorológicas en dos islas del archipiélago de Palmer (al sur del estrecho de Gerlache). Los datos fueron obtenidos durante la III Expedición Antártica Colombiana en el verano austral 2016-2017. Las series de temperatura del aire, humedad relativa, punto de rocío, dirección del viento y velocidad del viento en la isla Doumer, se compararon con las registradas en la isla Anvers y con el comportamiento de la temperatura del mar a 10 metros de profundidad en la bahía Sur (isla Doumer). Se concluyó que aunque las islas Anvers y Doumer son vecinas, el comportamiento de las variables meteo-marinas en el verano austral 2016-2017 difiere.

\section{Palabras clave:}

Oeste de la península Antártica, archipiélago de Palmer, meteorología, temperatura marina.

\section{INTRODUCTION}

Given the strong regional differences present in the white continent and the fact that is considered one of the global warming hotspots (IPCC, 2014), the Western Antarctic Peninsula (WAP) is one of the places that attracts a great deal of interest worldwide for its study. Nevertheless, there has been few studies focused on the research of atmospheric and oceanographic conditions

\footnotetext{
Universidad Nacional de Colombia. Departamento de Geociencias. Cra. 30 N45-03. Ed. 224, Of. 331. Bogotá,

Colombia. $\bowtie$ nlvillegasb@unal.edu.co

2 Grupo de investigación en oceanología CENIT. Cra. 32A No25B-75. Bogotá, Colombia. ig_nan@yahoo.com

3 Departamento Científico, Instituto Antártico Chileno Plaza Muñoz Gamero 1055. Punta Arenas, Chile. ccardenas@inach.cl
} 
in the South Bay (Doumer Island), located in the Palmer Archipelago, WAP.

In addition, few studies have been done on the meteorological conditions on the Gerlache Strait southern sector, where the mountainous island of Anvers is located, part of Palmer Archipelago (Griffith, 1988). For example, Pincheira et al. (1986) described the islands and islets in the region only from a geological point of view. Bliss et al. (2013) classified the ice cover in the Antarctic periphery based on the Antarctic Digital Database (ADD), where the Anvers and Doumer Islands were considered in the categories of mountain glacier and ice cap without a detailed meteorological description during the observational period. Thomas et al. (2015) presented an interesting work in a place located more southern of our study area analyzing ice core records from Ellsworth Land, West Antarctica, which revealed a twentieth-century increase in regional snow accumulation.

Several studies on marine biology and ecology were carried out in South Bay during the 70-80s (e.g. Moreno et al. 1977; Moreno \& Osorio, 1980; Moreno, 1980; Zamorano, 1983; Zamorano et al. 1986). A study related to climate change was initiated by Cárdenas (2016) who focused on the effect of global warming on Antarctic sponges in South Bay, and later on, Cárdenas et al. (2018) reported within-year (20162017) variation in seawater temperature at three sites at South Bay, Doumer Island.

The aim of this work is to contribute to the knowledge of the WAP describing some observed meteomarine conditions in South Bay and identifying meteorological differences in two islands of the Palmer Archipelago (south of Gerlache Strait). In order to achieve this, weather behavior from South Bay was monitored (in four defined local hours) by temporarily established two coastal stations and one in Stokes Hill, and atmospheric behavior from Doumer and Anvers islands was compared using data of two permanent automatic stations. Also, sea temperature at $10 \mathrm{~m}$ depth of South Bay was revised in regards to its response to meteorological conditions in Doumer Island.

\section{MATERIALS AND METHODS}

The study area is shown in the Fig. 1. South Bay is an Antarctic Specially Protected Area (DNA,
2010), located on Doumer Island, where the Chilean scientific base Yelcho operates during the Austral summer. Weather data on Doumer Island comes from 4 different points. Three of them were observed by temporarily established stations during the III Colombian Antarctic Expedition between January 16 and 27, 2017 (point E1 located on Stokes Hill at 64'52'42.9' 'S-63'35'21.6' $\mathrm{W}$ and coastal points E2 at $64^{\circ} 52^{\prime} 33.4^{\prime \prime}$ S- $63^{\circ} 35^{\prime} 04.7^{\prime \prime} \mathrm{W}$ and E3 at 64'52'33.1'S-63'34'59'W). Due to logistical reasons, meteorological information in these three points was recorded only at four local hours: 11 a.m., 2 p.m., 5 p.m. and 11 p.m. The record interval was 20 seconds averaged to 2 minutes with a Kestrel Weather Meter. The fourth point corresponded to the Oregon Scientific Automatic Weather Station (AWS) of Yelcho Base installed at 6452'38' S, 63³4'59.8'W on Stokes Hill by the Instituto Antártico Chileno (INACH) with observations averaged to 5 minutes from December 25, 2016 to February 16, 2017. For the same period, meteorological information averaged to 5 minutes was obtained from the Antarctic Meteorological Research Center (AMRC, 2017), recorded by the Palmer Automatic Weather Station (PAWS) which is situated on the Anvers Island at $64^{\circ} 46^{\prime} 27.3^{\prime \prime} S 64^{\circ} 03^{\prime} 12.0 \prime \mathrm{W}$. This island is located towards the west of Doumer Island separated by the Neumeyer Channel. Finally, the sample lengths obtained during 12 observational days for each selected hour were 180 for E1, E2 and E3, and 144 for Palmer PAWS and Yelcho AWS. Table 1 shows the t-values obtained by testing the statistically significant differences between the data sets. Seawater Temperature $\left({ }^{\circ} \mathrm{C}\right)$ was obtained from a $\mathrm{HOBO}{ }^{\circledR}$ onset device (PY1) installed by INACH at $10 \mathrm{~m}$ depth in South Bay at 64²' $28.1^{\prime \prime S}-63^{\circ} 34^{\prime} 36.0^{\prime \prime W}$. The hourly series from 25 December 2016 to 16 February 2017 recorded by AWS at Yelcho Base and by the HOBO device at South Bay (being a 1296 sample length, t-values 9.6 and 5.4 respectively, $\mathrm{p}<0.001$ ) were averaged daily to plot, compare and describe the behavior of Seawater Temperature and meteorological conditions. The observed meteorological data were Air temperature $\left(\mathrm{Ta},{ }^{\circ} \mathrm{C}\right)$, Relative humidity ( $\mathrm{Hr}, \%)$, Dew point temperature $\left(\mathrm{Td},{ }^{\circ} \mathrm{C}\right)$, Wind direction (Vd, degrees) and Wind speed (Vv, m/s). 

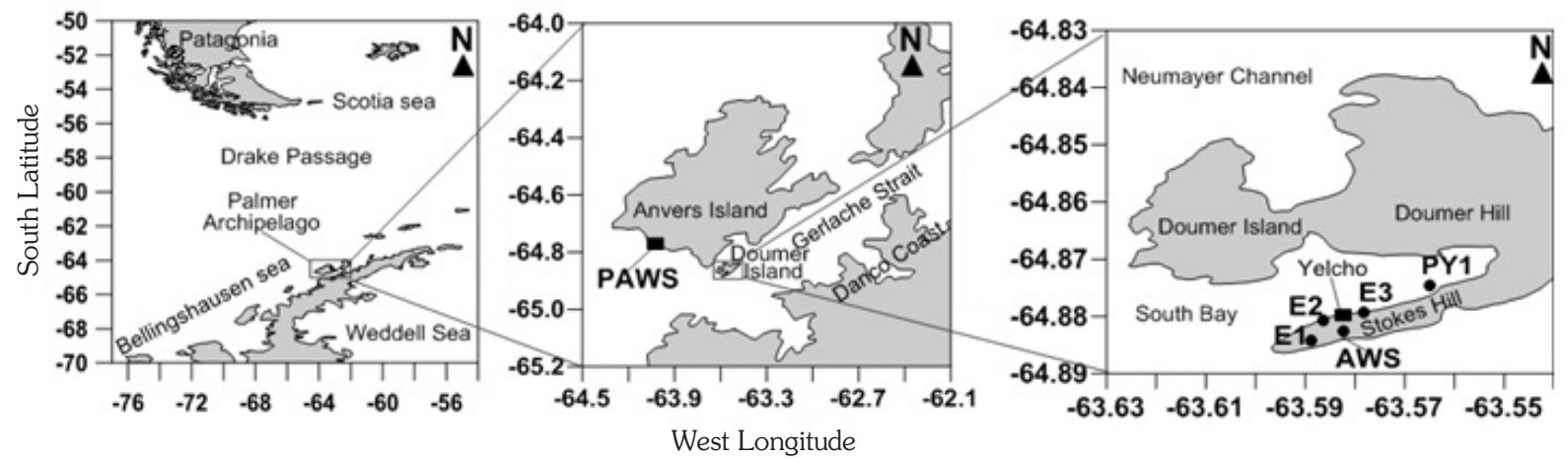

Fig. 1. Location of South Bay, Doumer and Anvers Islands. Observation points: AWS (6452'38' S, 6334'59.8' 'W);

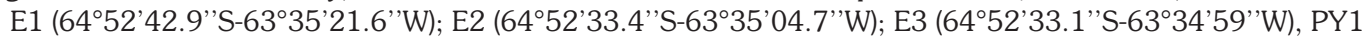

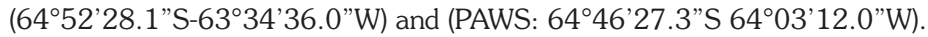

Table 1. T-values obtained by testing the statistically significant differences between the data sets. Compared data sets at different hours: 1: Coastal E2 - PAWS; 2: Coastal E2 - AWS; 3: PAWS - AWS; 4: Stokes Hill E1 - PAWS; 5 : Stokes Hill E1 - AWS; 6: Coastal E3 - PAWS; 7: Coastal E3 - AWS; 8: Stokes Hill E1 - PAWS; 9: Stokes Hill E1 AWS. Differences are significant at ${ }^{*} \mathrm{P}<0.001,{ }^{* *} \mathrm{P}<0.05$.

\begin{tabular}{cccccccccccc}
\hline & 11 & \multicolumn{1}{c}{14} & \multicolumn{1}{c}{17} & \multicolumn{3}{c}{23} \\
\hline 1 & 2 & 3 & 4 & 5 & 3 & 6 & 7 & 3 & 8 & 9 & 3 \\
\hline$* 6.9$ & $* 9.8$ & $* * 1.8$ & $* 8.7$ & $* 7.7$ & $* 3.4$ & $* 4.5$ & $* 4.6$ & $* 7.6$ & $* 12.6$ & 1.1 & $* 10.7$ \\
\hline
\end{tabular}

\section{RESULTS}

During the observing period from 16-27 January 2017 (which could be considered as short), the most noticeable meteorological condition found was that from 16 to 23 January 2017 the predominant wind direction was West while during 24 to 27 January 2017 it was Northeast (Fig. 2). This condition was found with data obtained by coastal stations E2 and E3 which were established temporarily while the III Colombian Antarctic Expedition lasted.

The average velocity during prevailed West winds corresponded to level 1 according to Beaufort scale (light) and a Sea State of 1 degree in Douglas Scale (smooth). The cloudiness was category 0 (sky completely clear), with a visibility of 9 which corresponds to a diaphanous atmosphere and excellent visibility according to the international scale. The average Ta during the West winds predominance was $3.2^{\circ} \mathrm{C}$, which was slightly lower than the one present during the Northeast winds predominance. The $\mathrm{Hr}$ was $70 \%$, due to the humidity that came from the ocean (through the Bismarck Strait) towards the South Bay.
When northeasterly winds were present, bad weather conditions were observed, the state of the sea was 3 on the Douglas scale (slight) and the winds recorded a higher mean velocity than the one present during the West winds, with an intensity of 3 (gentle breeze) on the Beaufort scale. Likewise, a cloudiness between partial and totally covered sky was observed, with a visibility of 5 (fog, poor visibility) according to the international scale. The average Ta was relatively higher than the one present during West winds predominance $\left(4.1^{\circ} \mathrm{C}\right)$. The observed $\mathrm{Hr}$ was $65 \%$, which is explained by the loss of moisture experienced by the air masses when descending from Doumer Hill, bringing rain to the South Bay.

The wind charts with data registered at 11 , 14, 17 and 23 hours from Anvers Island (PAWS at the Palmer base) and Doumer Island (at the coastal observation points E2, E3 and at the observation points on Stokes Hill E1 and AWS) during January 16 to 27,2017 , show that the weather conditions during this period were different between these two islands, which are located close to each other in the south of the Gerlache Strait (Fig. 3). 

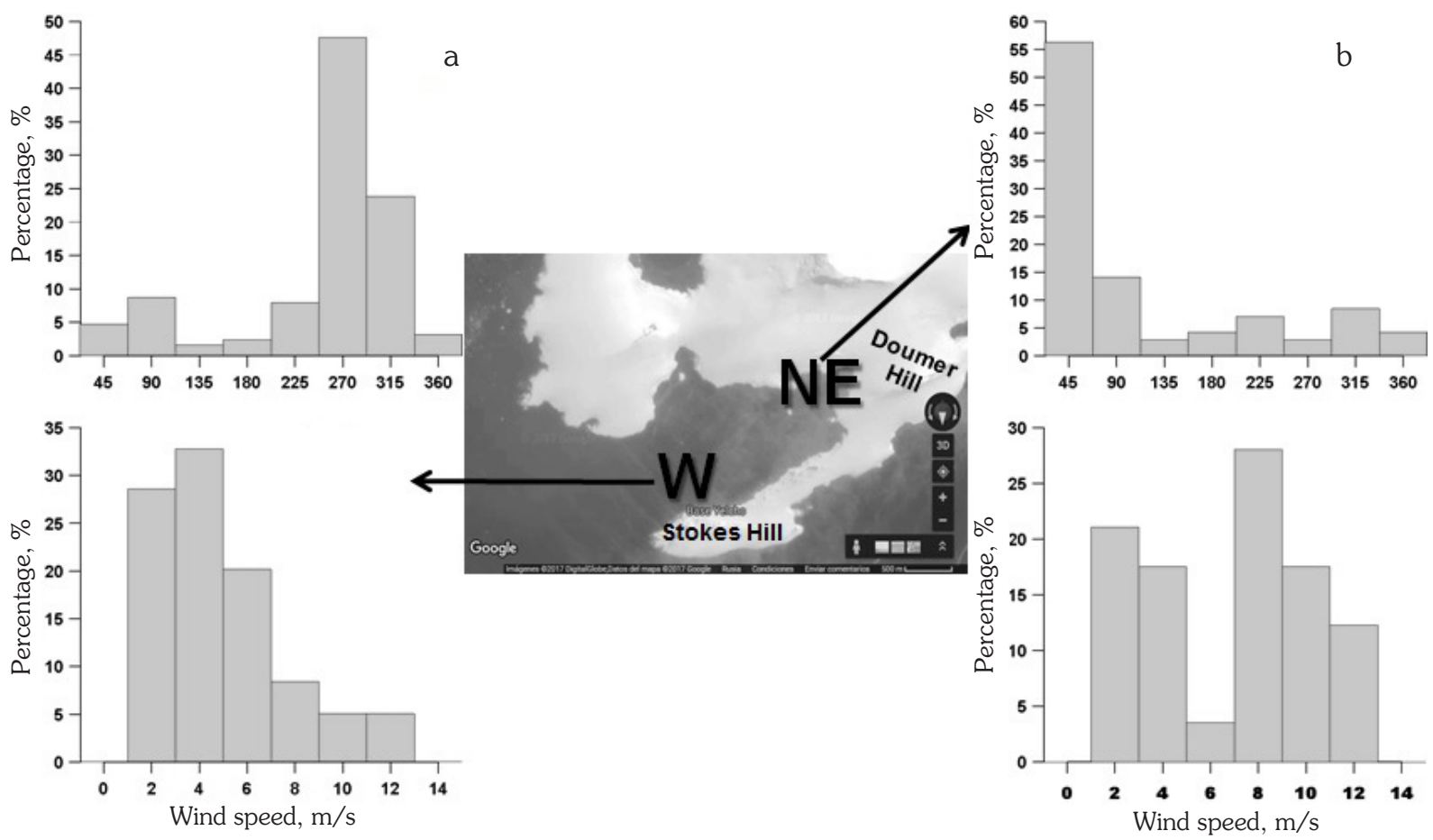

Fig. 2. Percentage of wind direction and wind velocity on the South Bay coast, Doumer Island. a. from 16 to 23, January 2017; b. from 24 to 27, January 2017.

It was observed that at 11 am the predominant wind in these two islands was NorthNortheast. This prevalence continued during the studied period in Doumer Island according to the average records on both the coast and Stokes Hill. In contrast, the data from Anvers Island shows large variability in wind direction, as records display an East-Southeast direction at 14 and 17 hours whereas the data from hour 23 depicts a NorthNorthwest direction.

The maximum, minimum and mean values of both $\mathrm{Ta}$ and $\mathrm{Hr}$ also differed between the two islands (Table 2). There was a larger Ta variation in Anvers Island than in Doumer, with daily amplitude of $7.1^{\circ} \mathrm{C}$, whereas in Doumer Island it was $5.7^{\circ} \mathrm{C}$ (according to coastal data) and $4.7^{\circ} \mathrm{C}$ (according to data on the Stokes Hill). In regards to $\mathrm{Hr}$, although the values were almost similar between the islands, Anvers Island presented the lowest minimum values. At both islands it was observed that $\mathrm{Hr}$ is lower during 11-14 hours.

In order to analyze the correspondence between the sea temperature in South Bay and the meteorological conditions at Doumer Island, Fig. 4 shows the daily behavior of sea temperature at 10 m depth, Ta, Hr and Td from 25 December 2016 to 16 February 2017.

As it can be seen in Fig. 4, Td and $\mathrm{Hr}$ on Doumer Island behave in a very similar manner as expected; a gradual decrease towards the end of 2016 and an increase from mid-observation period towards its end. It was also observed that during the periods of 28 December 2016 to 4 January 2017 and 27 January 2017 to 7 February 2017, there were some instances where the differences between $\mathrm{Ta}$ and $\mathrm{Td}$ were minimal. It was also observed during these periods, that increases in $\mathrm{Hr}$ concurred to increases in sea temperature at $10 \mathrm{~m}$ depth.

Even though this behavior is consistent with the theory, it is required to have Sea Surface Temperature (SST) data in order to corroborate the heating or cooling time response of South Bay surface waters as a reaction to the meteorological conditions. It is essential to combine the satellite images analysis to understand the spatial distribution of sea temperature in South Bay with meteorological data on the coast and in situ data from the bay. 


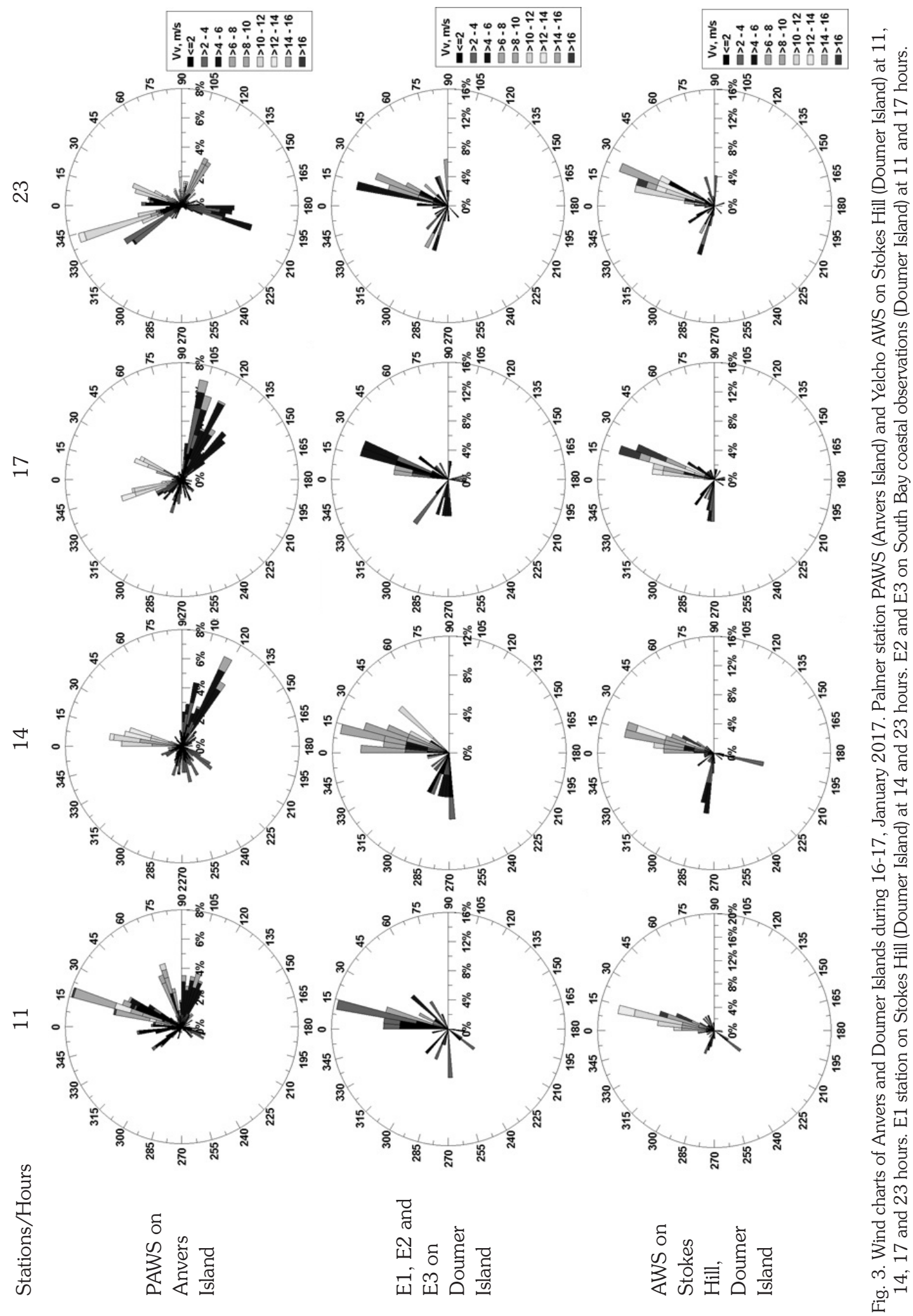




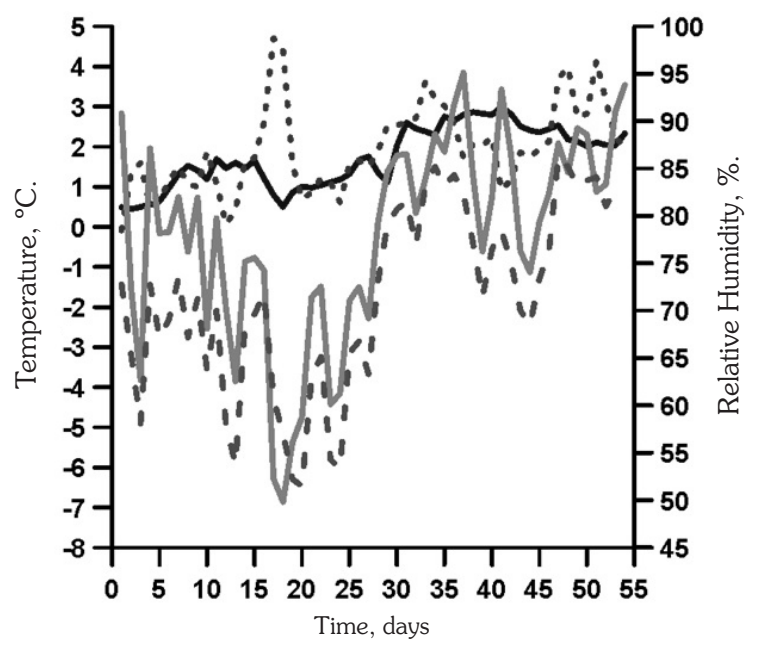

- Sea Temperature at $10 \mathrm{~m}$ depth, ${ }^{\circ} \mathrm{C}$.
Air Temperature, $\mathrm{Ta},{ }^{\circ} \mathrm{C}$.

Relative Humidity. $\mathrm{Hr}, \%$

- $\quad$ Dew Point Temperature. $\mathrm{Td},{ }^{\circ} \mathrm{C}$.

Fig. 4. Daily behavior of Sea Temperature on South Bay (Doumer Island) at $10 \mathrm{~m}$ depth (64'52'28.1' 'S-63'34'36.0"W) and Ta, Hr and Td on Stokes Hill (Doumer Island) measured by AWS (645'ㅇ's, 6334'59.8'’W) from 25 December 2016 to February 2017.

Table 2. Ta and Hr maximum, minimum and average during 16-27, January 2017. Palmer station PAWS (Anvers Island) and Yelcho AWS on Stokes Hill (Doumer Island) at 11, 14, 17 and 23 hours. E1 station on Stokes Hill (Doumer Island) at 14 and 23 hours. E2 and E3 on South Bay coastal observations (Doumer Island) at 11 and 17 hours.

\begin{tabular}{|c|c|c|c|c|c|c|c|c|c|c|c|c|}
\hline \multirow{3}{*}{ Observational stations } & \multicolumn{4}{|c|}{ Maximum } & \multicolumn{4}{|c|}{ Minimum } & \multicolumn{4}{|c|}{ Average } \\
\hline & 11 & 14 & 17 & 23 & 11 & 14 & 17 & 23 & 11 & 14 & 17 & 23 \\
\hline & \multicolumn{12}{|c|}{ Air temperature, ${ }^{\circ} \mathrm{C}$} \\
\hline PAWS, Anvers Island & 6.7 & 6.2 & 7.4 & 6.4 & 0.3 & 1.3 & 2.1 & 1.4 & 2.8 & 3.3 & 3.8 & 3.2 \\
\hline $\begin{array}{l}\text { E1, E2 and E3, Doumer } \\
\text { Island }\end{array}$ & 5.9 & 3.5 & 4.6 & 4.2 & 1.4 & 2.0 & 2.5 & -0.2 & 4.1 & 2.4 & 3.2 & 1.5 \\
\hline \multirow[t]{2}{*}{ AWS, Doumer Island } & 5.1 & 3.9 & 4.1 & 4.4 & 1.0 & 1.4 & 1.6 & -0.4 & 2.5 & 3.0 & 2.8 & 1.7 \\
\hline & \multicolumn{12}{|c|}{ Relative humidity, \% } \\
\hline PAWS, Anvers Island & 88 & 84 & 88 & 89 & 47 & 43 & 42 & 51 & 70 & 68 & 67 & 71 \\
\hline $\begin{array}{l}\text { E1, E2 and E3 Doumer } \\
\text { Island }\end{array}$ & 88 & 87 & 88 & 92 & 45 & 52 & 58 & 50 & 67 & 65 & 66 & 76 \\
\hline AWS, Doumer Island & 90 & 91 & 94 & 90 & 55 & 55 & 52 & 63 & 75 & 74 & 75 & 82 \\
\hline
\end{tabular}

\section{DISCUSSION}

As it can be appreciated in this paper, there are certain differences in the meteorological behavior between both islands and also between the coast and Stokes Hill within the Doumer Island. The fact that the only permanent station present in Doumer Island is on Stokes Hill, suggests that it is also required to establish a station in the South Bay coast of Doumer Island. Thus, the coastal information from both islands could be more adequately compared and the meteomarine conditions of South Bay could be better represented.

The climate in the Antarctic Peninsula (AP) is framed by two circulation regimes that 


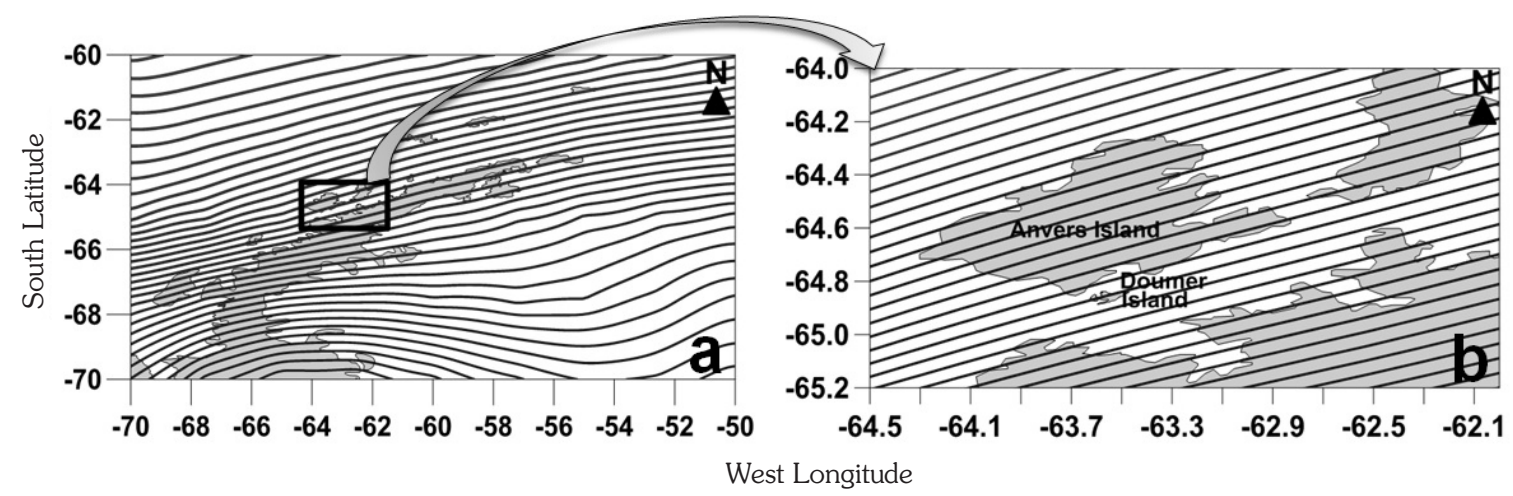

Fig. 5. Spatially distributed isotherms in parallel with the AP. Average Ta for the period January 1948 - December 2016 (Kalnay et al. 1966). Gradual Ta decrease from northwest toward south and south-east. a: from $2.15^{\circ} \mathrm{C}$ to $-16.0^{\circ} \mathrm{C}$ with $0.5^{\circ} \mathrm{C}$ interval. b: from $-3.76^{\circ} \mathrm{C}$ to $-7.12^{\circ} \mathrm{C}$ with $0.1^{\circ} \mathrm{C}$ interval.

are clearly seen when observing the spatially distributed isotherms in parallel with the AP (Fig. 5). The two different types of climate in the AP are explained also by its topographical features. The high mountains of the AP act as a barrier to the tropospheric circulation of West-East direction which leads to the diversion of cyclonic storms and increased precipitation $(\mathrm{Pr})$ in the Palmer Archipelago and the South Shetland Islands in relation to the South and East zones (Dewar, 1967). The differences in Ta and Pr combined generate a maritime climate on the West Coast and a pseudocontinental climate on the East Coast (Reynolds, 1981). Therefore, the Gerlache Strait, located in the WAP, is characterized by higher values of $\mathrm{Pr}$, $\mathrm{Hr}$ and $\mathrm{Ta}$ in relation to other Antarctic sectors, which was observed by Sadler (1968), Krebs (1974) and Alarcón et al. (1976). In relation to the winds Rundle (1971) reported that these are persistent along the coast and in the islands in the AP, with the Southwest wind is the predominant one. These predominant winds bring low clouds of type stratus which characterize the zone; although previously, Giles (1963) found that the passage of low pressure systems interrupts the relatively moderate weather.

The greater amount of Pr during the time of the year, when there is less sea ice present, probably reflects the fact that the fronts passing down the AP are more active in the more northerly part of the region (Turner et al. 1997). As the cyclonic storms pass along the peninsula, strong East and East-northeast winds arrive, bringing with them large quantities of Pr, which could explain the weather condition observed during the prevalence of northeast winds on Doumer Island in such a short period described in the present work. However, it can also be suggested that Doumer Island is influenced by pressure systems which move along the west coast of the AP and come from Amundsen Sea. These pressure systems bring a large amount of moisture making the precipitation process viable which could help to understand why this is the wettest part of Antarctica. According to Láska (2016), the highest average annual rainfall in Antarctica has been registered in the WAP, with rain and drizzle being the most common processes, as observed during the last days of monitoring for the present analysis. Láska (2016) suggests that the Pr does not seem to be related to seasons, but rather to the passage of cyclonic storm systems from the Bellingshausen Sea. Rundle (1971) and later Grieger et al. (2016) based on pressure records taken from Palmer station, state that storms appear to occur with a frequency of 1 major storm every 3 weeks during the year.

These conditions have been changing in recent years and will continue to do so as shown by Turner et al. (2013) and Bracegirdle et al. (2015) via their numerical modeling projection. The same assumption about changing weather conditions is being suggested by the data presented in this work taking the two islands as a reference (Doumer and Anvers Islands), where two different weather conditions are identified, although both islands are located in WAP. In the study region, as well is possible to observe the parallel Ta spatial 
distribution which shows the gradual decrease of Ta toward south and south-east (Fig. 5). This also could be due to the geographical particularities of the two islands. Anvers Island has a direct exposure to the sea, while Doumer Island is more enclosed within the Palmer Archipelago. In addition, the weather of Doumer Island depends on the direction of the prevailing wind, causing that in some periods it has the influence of the sea, but in others, it has the influence of the Doumer Hill.

The present work shows the importance of carrying out more research looking for the relationship between the characteristics of Antarctic cyclones and surface meteorological properties, which allows a better explanation of the weather conditions in the study area, as was done by Uotila et al. (2011) and Pezza et al. (2016).

As stated by Carrasco et al. (2003), mesoscale cyclones contribute to the annual amount of precipitation in many coastal areas of the Antarctic and occasionally, they can develop into major features causing moderate and severe weather conditions. Precisely because the WAP is experiencing a faster warming than other sectors of this region (Ducklow et al. 2013), the processes of cyclogenesis could be changed as well, causing that some regions in the WAP to experience unusual variations affecting weather conditions even in small sectors which are very close as Anvers and Doumer Islands. For example, near Anvers Island according to Reanalysis data (Kalnay et al. 1996) multi-year Ta average (1948 - 2015) for December is $-1.03^{\circ} \mathrm{C}$, January $-0.35^{\circ} \mathrm{C}$ and February $-0.54^{\circ} \mathrm{C}$. Taking the same database the mean air temperature in December 2016 was $-1.24^{\circ} \mathrm{C}$, in January 2017 was $0.09^{\circ} \mathrm{C}$ and $0.83^{\circ} \mathrm{C}$ in February 2017. Therefore, a negative anomaly $-0.21^{\circ} \mathrm{C}$ was presented in December 2016, and positive anomalies of $0.44^{\circ} \mathrm{C}$ and $1.37^{\circ} \mathrm{C}$ were registered in January and February 2017 respectively.

The fact that the data for the present work were obtained in a relatively short period of time, reaffirms the importance of improving the monitoring on this part of Gerlache Strait in order to obtain more extensive series of meteorological data allowing the study of meteo-marine characteristics in the region and the explanation of why Anvers Island presented more pronounced meteorological variations than Doumer Island did. Likewise, for the analysis of weather in South Bay, it is recommended to combine meteo-marine information observed in permanent coastal stations with satellite images interpretation.

\section{CONCLUSIONS}

During the brief observing period, it was made evident that the meteo-marine conditions of South Bay (Doumer Island) are influenced by the mild Western marine winds, which bring with them a characteristic good weather, and higher intensity mountainous North-eastern winds which bring bad weather to the area.

Although the Anvers and Doumer Islands are both located towards the south of the Gerlache Strait and close to each other, the behavior of the meteo-marine variables described for the austral summer 2016-2017 differ slightly. This could be due to their geographical particularities such as Anvers Island exposure to the sea and the influence that Doumer Hill has on Doumer Island.

Meteorological conditions recorded daily at Stokes Hill in Doumer Island, showed that increases in $\mathrm{Hr}$ concurred to increases in sea temperature at $10 \mathrm{~m}$ depth in South Bay.

The results suggest the improvement of the monitoring at the study area and demonstrate the importance of the meteorological and oceanographic research of the Gerlache Strait southern sector.

In order to clarify the meteo-marine conditions of South Bay is necessary to establish a meteorological coastal station as currently the only station in Doumer Island is located on Stokes Hills and therefore its data is not representative of South Bay.

It is suggested to combine satellite images analysis, coastal meteorological data and in situ data from this study area in order to understand the spatial distribution of sea temperature in South Bay.

\section{ACKNOWLEDGMENTS}

Thanks to Programa Antártico Colombiano (PAC), Instituto Antártico Chileno (INACH), Universidad Nacional de Colombia, Armada Nacional de Colombia, Armada de Chile and Fuerza Aérea 
de Chile (FACH), for the collaboration and funding of this work. The deployment of data loggers to record seawater temperature was supported by CONICYT/FONDECYT/INACH/ INICIACION/\#11150129 granted to CAC. The authors appreciate the support of the University of Wisconsin-Madison Automatic Weather Station Program for the data set, data display, and information, NSF grant number ANT-1543305. We thank reviewers for their insightful comments that substantially improved the manuscript.

\section{LITERATURE CITED}

Alarcón, B., Ambrus, J., Olkay, L., \& Vieria, C. (1976). Geología del Estrecho de Gerlache entre los paralelos 64 y 65 Lat. Sur. Antárctica Chilena. Instituto Antárctico Chileno. Serie Científica Instituto Antártico Chileno, 4, 7-46.

AMRC. (2017). Antarctic Meteorological Research Center (AMRC) and Automatic Weather Station (AWS). Palmer Station Antarctica Automated Weather Station. ftp://amrc.ssec.wisc.edu/pub/palmer/. Accessed 1 March 2017.

Bliss, A., Hock, R., \& Cogley, J. (2013). A new inventory of mountain glaciers and ice caps for the Antarctic periphery. Annals of Glaciology, 54(63), 191-199.

Bracegirdle, T. J., Stephenson, D. B., Phillips, T., \& Turner, J. (2015). The importance of sea-ice extent biases in 21st century multimodel projections of Antarctic temperature and precipitation. Geophysics Research Letters, 42(24), 10832-10839.

Cárdenas, C. (2016). In union there is strength. Coexistence between Antarctic sponges and other organisms facing a changing environment. Advances in Chilean Antarctic Science, 3, 6-9.

Cárdenas, C. A, González-Aravena, M., \& Santibañez, P.A. (2018). The importance of local settings: within-year variability in seawater temperature at South Bay, Western Antarctic Peninsula. PeerJ 6:e4289.

Carrasco, F., Bromwich, D., \& Monaghan, A. (2003). Distribution and Characteristics of Mesoscale Cyclones in the Antarctic Ross
Sea Eastward to the Weddell Sea. Monthly Weather Review, 131, 289-301.

Dewar, G. (1967). Some aspects of topography and glacierozation of Adelaide Island. British Antarctic Survey Bulletin, 11, 37-47.

DNA. (2010). Guía para la protección del medio ambiente Antártico - Cuadernillo 4: Áreas Protegidas. Dirección Nacional del Antártico. Argentina. Instituto Antártico Argentino.

Ducklow, H., Fraser, W., Meredith, M., Stammerjohn, S., Doney, S., Martinson, D., Sailley, S.,... \& Amsler, C. (2013). West Antarctic Peninsula: An ice-dependent coastal marine ecosystem in transition. Oceanography, 26(3), 190-203.

Giles, B. (1963). Vector mean winds at the Argentine Islands, Graham Land 19541958. British Antarctic Survey Bulletin, 1, 33-40.

Grieger, J., Leckebusch, G., \& Ulbrich, U. (2016). Net precipitation of Antarctica: Thermodynamical and dynamical parts of the climate change signal. Journal of Climate, 907-924.

Griffith, T. (1988). A geological and geophysical investigation of sedimentation and recent glacial history in the Gerlache Strait region, Graham Land, Antarctica. Thesis Master of Arts. Department of Geology and Geophysics. Rice University. USA.

IPCC. (2014). Climate Change 2014: Synthesis Report. Contribution of Working Groups I, II and III to the Fifth Assessment Report of the Intergovernmental Panel on Climate Change [Core Writing Team, R. K. Pachauri \& L. A. Meyer (Eds.)]. IPCC, Geneva, Switzerland.

Kalnay et al. (1996). The NCEP/NCAR 40-year reanalysis project, Bulletin of the American Meteorological Society, 77, 437-470.

Krebs, W. (1974). Physico-chemical oceanography of Arthur Harbor, Anvers Island. Antarctic Journal of the United States, 9, 219-221.

Láska, K. (2016). Response of biotic and abiotic environments on climate variability in the region of the Antarctic Peninsula and Svalbard Archipelago. Ph.D. thesis. Brno, Czech Republic. Department of Geography. 
Faculty of Science. Masaryk University. Moreno, C. A., Zamorano, J. H., \& Duarte, W. E. (1977). Distribución y segregación espacial de las poblaciones de peces en bahía South (Isla Doumer, Antártica). Serie Científica Instituto Antártico Chileno, 5(1), 45-48.

Moreno, C. A., \& Osorio, H. H. (1980). Bathymetric food habit changes in the Antarctic fish, Notothenia gibberifrons Lönnberg (Pisces: Nothotheniidae). Hydrobiologia, 55(2), 139-144.

Moreno, C. A. 1980. Observations on food and reproduction in Trematomus bernacchii (Pisces: Nototheniidae) from the Palmer Archipelago, Antarctica. Copeia, 1, 171173.

Pezza, A., K. Sandler, P. Uotila, T. Vihma, M. Mesquita, \& P. Reid (2016). Southern Hemisphere strong polar mesoscale cyclones in high-resolution datasets. Climate Dynamics, 47(5-6), 1647-1660.

Pinchiera, M., Pereira, M., Hoecker, G., \& Abad, E. (1986). Antecedentes geológicos y ocurrencias de mineralización en el sector sur del estrecho de Gerlache, península Antártica. Serie Científica INACH, 34, 9-22.

Reynolds, J. (1981). The distribution of mean annual temperatures in the Antarctic Peninsula. British Antarctic Survey Bulletin, 54, 123-133.

Rundle, A. (1971). Glacialogy and meteorology of Anvers Island: subglacial Surface of Marr Ice Piedmont. Antarctic Journal of the United States, 6, 202-206.
Sadler, I. (1968). Observations on the ice caps of Galindez and Skua Islands, Argentine Islands, 1960-1966. British Antarctic Survey Bulletin, 17, 21-49.

Thomas E. R., Hosking J. S., Tuckwell R. R., Warren R. A., \& Lulow E. C. (2015). Twentieth century increase in snowfall in coastal West Antarctica. Geophysical Research Letters, 42, 9387-9393.

Turner, J., Colwell, S. R., \& Harangozo, S. (1997). Variability of precipitation over the coastal western Antarctic Peninsula from synoptic observations. Journal of Geophysical research, 102, D12, 13999-14007.

Turner, J., Barrand, N. E., Bracegirdle, T. J., Convey, P., Hodgson, D. A., Jarvis, M., Jenkins, A.,... \& Klepokov, A. V. (2013). Antarctic climate change and the environment: An update. Polar Record, 50(3), 237-259.

Uotila, P., Vihma, T., Pezza, A. B., Simmonds, I, Keay, K., \& Lynch, A. H. (2011), Relationships between Antarctic cyclones and surface conditions as derived from highresolution numerical weather prediction data. Journal of Geophysical Research, 116, D07109.

Zamorano, J. H. (1983). Zonación y biomasa de la macrofauna bentónica en Bahía South, Archipiélago de Palmer, Antártica. Serie Científica Instituto Antártico Chileno, 30, 27-38.

Zamorano, J. H., Duarte, W. E., \& Moreno, C.A. (1986). Predation upon Laternula elliptica (Bivalvia, Anatinidae): a field manipulation in South Bay. Polar Biology, 6, 139-143. 